\title{
Investigation of Antioxidant and Antimicrobial Activities of Different Extracts of Auricularia and Termitomyces Species of Mushrooms
}

\author{
Gebreselema Gebreyohannes $\mathbb{D}^{\mathrm{D}},{ }^{1,2}$ Andrew Nyerere, ${ }^{3}$ Christine Bii, ${ }^{4}$ and Desta B. Sbhatu $\mathbb{D}^{1}$ \\ ${ }^{1}$ Department of Biological and Chemical Engineering, Mekelle Institute of Technology, Mekelle University, Ethiopia \\ ${ }^{2}$ Molecular Biology and Biotechnology, Pan African University, Institute for Basic Sciences, Technology, and Innovation, Nairobi, Kenya \\ ${ }^{3}$ Department of Medical Microbiology, College of Health Sciences, Jomo Kenyatta University of Agriculture and Technology, \\ Nairobi, Kenya \\ ${ }^{4}$ Center for Microbiology Research, Kenya Medical Research Institute, Nairobi, Kenya
}

Correspondence should be addressed to Gebreselema Gebreyohannes; gselamta21@gmail.com

Received 22 March 2019; Revised 11 June 2019; Accepted 2 July 2019; Published 24 July 2019

Academic Editor: Monika Wujec

Copyright (C) 2019 Gebreselema Gebreyohannes et al. This is an open access article distributed under the Creative Commons Attribution License, which permits unrestricted use, distribution, and reproduction in any medium, provided the original work is properly cited.

\begin{abstract}
Mushrooms produce a variety of bioactive compounds that are known to have a potential source of antioxidant and antimicrobial properties. Natural antioxidants can protect against free radicals without any side effects. The purpose of this study was to evaluate the antioxidant and antimicrobial activities of Auricularia and Termitomyces extracts. Specimens of Auricularia and Termitomyces spp. were collected from Kakamega National Reserve Forest in Kenya. Specimens were identified, extracted, and screened for their antioxidant and antimicrobial activities using stable free radical DPPH and colorimetric bioassay methods, respectively. The antimicrobial activity of the extracts was tested against Escherichia coli, Klebsiella pneumoniae, Pseudomonas aeruginosa, Staphylococcus aureus, MRSA, Candida albicans, and Candida parapsilosis. The maximum scavenging activity of hot water extract of Auricularia spp. was observed at $70.4 \%$ with the $\mathrm{IC}_{50}$ value of $40 \mu \mathrm{g} / \mathrm{mL}$. Of the three extracts of Termitomyces spp., $70 \%$ ethanol extract has shown the highest scavenging activity $(63 \%)$ with the $\mathrm{IC}_{50}$ value of $50 \mu \mathrm{g} / \mathrm{mL}$. Chloroform and hot water extracts of Auricularia have shown statistically significantly different antifungal activities against $C$. parapsilosis $(d f=2, \mathrm{~F}=22.49, p \leq 0.05)$. Of all the organisms, S. aureus was highly susceptible to $70 \%$ ethanol and hot water extracts of Termitomyces spp. with minimum inhibitory concentration values of $0.67 \pm 0.29 \mathrm{mg} / \mathrm{mL}$. S. aureus and E. coli were the most susceptible and resistant bacteria to the hot water extract, respectively. In conclusion, the extracts of Auricularia spp. and Termitomyces spp. have shown promising antimicrobial and antioxidant activities.
\end{abstract}

\section{Introduction}

In the last few years, several antimicrobial and antioxidant compounds were discovered from the Fungi Kingdom $[1,2]$. Mushrooms possess enormous biologically active secondary metabolites for different applications [3-7]. Moreover, they have a wide range of secondary metabolites of high therapeutic values such as antioxidant, diabetes, antiviral, antithrombotic, anti-inflammatory, and antitumor activities [8-10]. It has been reported that a total of 316 mushroom species extracts have shown antimicrobial activities against Grampositive and Gram-negative bacteria [11-13].
Though most mushroom species, if not all, are immensely rich in bioactive compounds, they are largely untapped resource of useful natural compounds [14, 15]. Evaluation of antioxidant and antimicrobial activities of mushroom extracts is currently the focus of the research [16]. However, the information about the effects of Auricularia and Termitomyces spp. extracts on antioxidant and antimicrobial activities is scarce. Extended knowledge of these mushroom species extracts may have remarkable importance to develop novel compounds that have antioxidant and antimicrobial benefits to be used as functional additives into our food regime to prevent damage caused by oxidation and pathogenic 


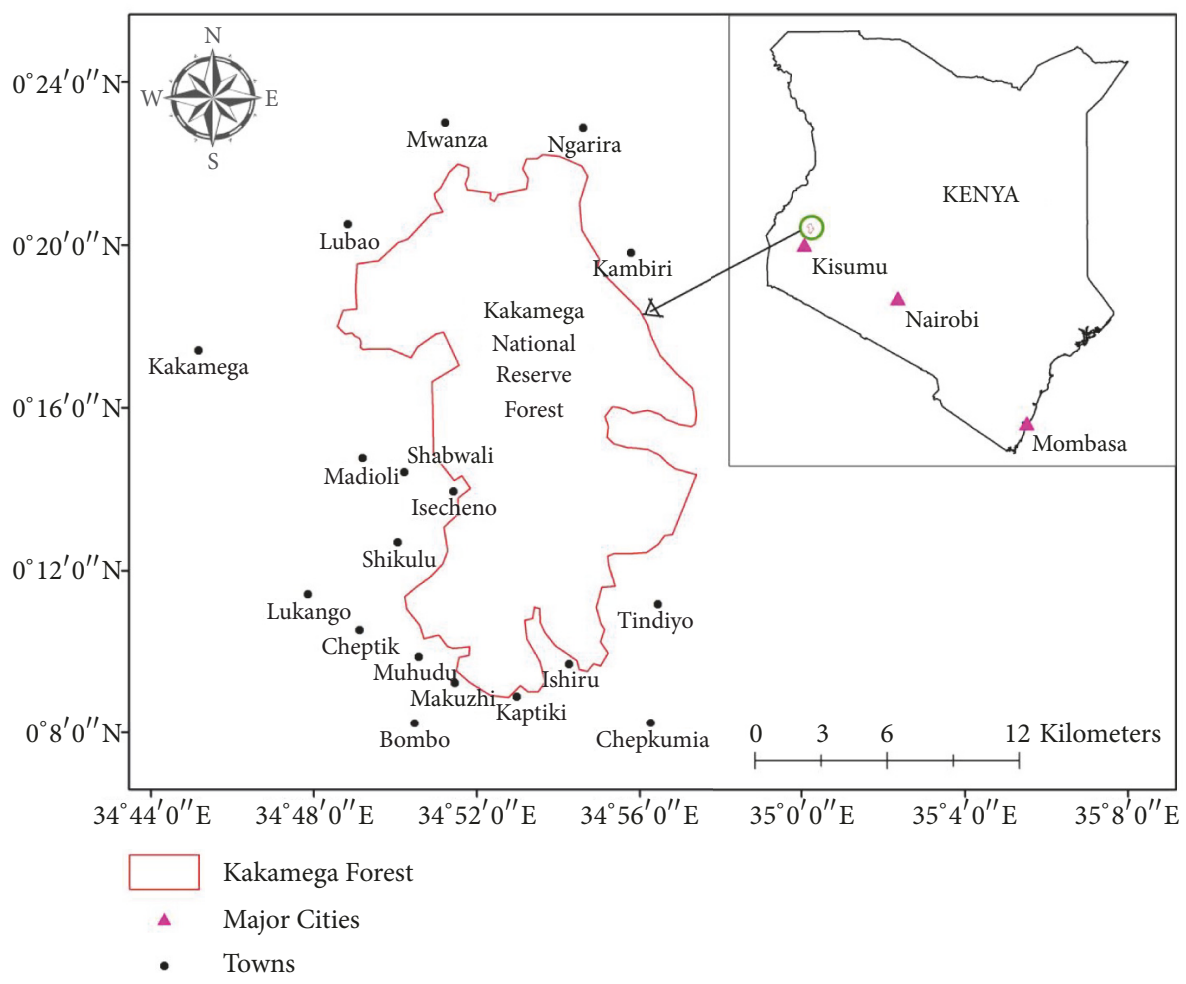

FIgURE 1: Map of the Kakamega National Reserve Forest.

organisms. Therefore, this study examined in vitro antioxidant and antimicrobial activities of chloroform, 70\% ethanol, and hot water extracts of the fruiting body of Auricularia and Termitomyces spp.

\section{Materials and Methods}

2.1. Collection and Identification of Mushroom Specimens. Specimens of Auricularia and Termitomyces indigenous wild mushrooms were collected from Kakamega National Reserve Forest in Kenya in the months of March and May 2017 (Figure 1). The specimens were identified using molecular analysis and taxonomical keys by comparing their morphological characteristics with related literature [17-21].

2.2. Extraction Process of the Mushroom Specimens. Mushroom extraction was carried out using chloroform, $70 \%$ ethanol, and distilled hot water [22]. Dry mushroom specimens were pulverized and $100 \mathrm{~g}$ of powder was mixed with $0.5 \mathrm{~L}$ of chloroform, $70 \%$ ethanol, and distilled hot water $\left(60^{\circ} \mathrm{C}\right)$ solvents in an Erlenmeyer flask at $25^{\circ} \mathrm{C}$ (Figure 2). The content was shaken using an incubator shaker at $150 \mathrm{rpm}$ for $72 \mathrm{~h}$. The extracts were centrifuged at $3000 \mathrm{rpm}$ for $15 \mathrm{~min}$, filtered with Whatman No. 1 filter paper, and dried by a rotary evaporator at $50^{\circ} \mathrm{C}$. The extracts were kept in $-80^{\circ} \mathrm{C}$ deep freezer and freeze dried. Finally, they were stored in the $4^{\circ} \mathrm{C}$ refrigerator in an amber colored bottle for further analyses.
2.3. Antioxidant Activities of the Extracts of Auricularia and Termitomyces spp. The antioxidant activity of the chloroform, $70 \%$ ethanol, and hot water extracts of Auricularia spp. and Termitomyces spp. was determined using the stable free radical DPPH with little modification from the previous method $[23,24]$. About $4 \mathrm{~mL}$ of $400 \mu \mathrm{M}$ of 2, 2-Diphenyl-1picrylhydrazyl (DPPH) was dissolved in chloroform, ethanol, and distilled water. Different concentrations of the extracts $(10,20,30,40,50,60$, and $70 \mu \mathrm{g} / \mathrm{mL})$ were prepared in a test tube and $1 \mathrm{~mL}$ of $400 \mu \mathrm{M}$ of DPPH was added. The mixture was shaken vigorously and left at room temperature for $60 \mathrm{~min}$ in a dark place until stable absorption values were obtained. Briefly, $1 \mathrm{~mL}$ of chloroform, $70 \%$ ethanol, distilled water, and DPPH were prepared without extracts as negative controls. The color change from purple to yellow was observed in terms of absorbance using a spectrophotometer at $517 \mathrm{~nm}$. Different concentrations of ascorbic acid (10, 20, $30,40,50,60$, and $70 \mu \mathrm{g} / \mathrm{mL}$ ) were prepared and used as a standard antioxidant (positive control). Radical scavenging activity was expressed as the inhibition percentage of free radical by the extracts and was calculated using the formula: $\% \mathrm{RSA}=[(\mathrm{ADPPH}-\mathrm{AS}) / \mathrm{ADPPH}] \mathrm{x} 100$, where $\mathrm{AS}$ is the absorbance of the solution (extract $+\mathrm{DPPH}$ ) and $\mathrm{ADPPH}$ is the absorbance of the DPPH solution. The assay was carried out in triplicate and the results were expressed as mean values \pm standard deviations. The extract concentration providing $50 \%$ inhibition $\left(\mathrm{IC}_{50}\right)$ was calculated from the graph of RSA percentage against extract concentration [25]. Likewise, the standard antioxidant (ascorbic acid) was calculated as 


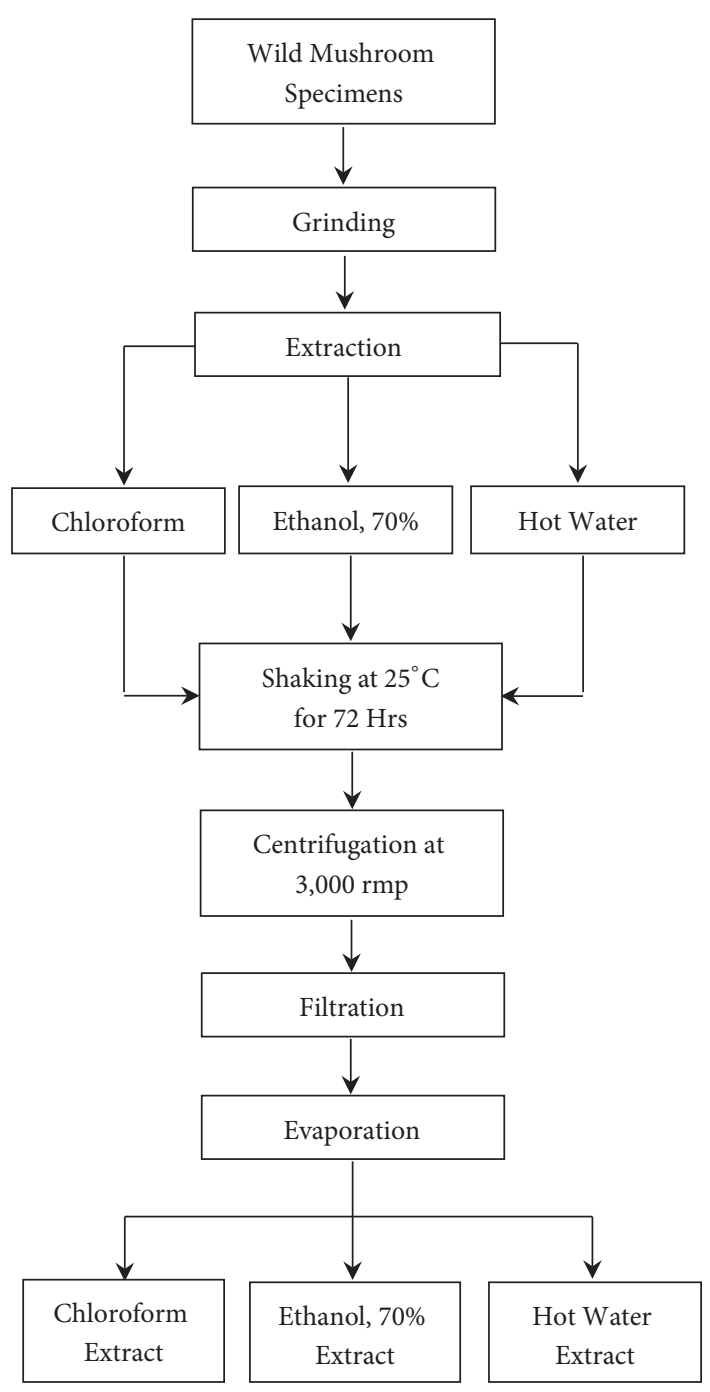

FIGURE 2: Extraction process of mushroom specimens.

a percentage of DPPH discoloration using the equation: \% $\mathrm{RSA}=[(\mathrm{ADPPH}-\mathrm{AAA}) / \mathrm{ADPPH}] \mathrm{X} 100$, where AAA is the absorbance of ascorbic acid.

2.4. Preparation of Test Organisms. Six bacterial species, E. coli (CI), K. pneumoniae (ATCC 13883), P. aeruginosa (CI and ATCC 27853), S. aureus (ATCC 25923), and MRSA (ATCC 33591) as well as two yeast species, $C$. albicans (CI) and $C$. parapsilosis (ATCC 90018), were used as test organisms. The bacterial species were grown in $5 \mathrm{~mL}$ of Mueller-Hinton broth at $37^{\circ} \mathrm{C}$ for $12-16 \mathrm{~h}$, while yeast species in $5 \mathrm{~mL}$ Sabouraud dextrose broth at $30^{\circ} \mathrm{C}$ for $24 \mathrm{~h}$. The inoculum size of each test organism was adjusted to a concentration of $1.5 \times 10^{8}$ $\mathrm{CFU} / \mathrm{mL}$ by comparing with $0.5 \mathrm{McF}$ arland standards.

2.5. Determination of Antimicrobial Activities of Mushroom Extracts. The AMA of mushroom extracts was determined using 2, 3, 5-triphenyl-tetrazolium chloride (TTC) microtiter plate bioassay. Stock solutions of mushroom extracts were prepared by dissolving $20 \mathrm{mg} / \mathrm{mL}$ of each extract in DMSO.
Moreover, Mueller-Hinton broth was prepared. First, $100 \mu \mathrm{L}$ of $\mathrm{MHB}$ was poured into each of the 96 ( 8 rows by 12 columns) wells of the microtiter plate. Then, the $100 \mu \mathrm{L}$ of the extract was added to Well \#1 in Row A and two-fold serial dilution was done through Well \#9. The Wells \#10, \#11, and \#12 were left with no mushroom extracts and were designated as "positive control," "quality control," and "negative control," respectively. Wells \#1 through \#9 in the remaining rows (rows $\mathrm{B}$ through $\mathrm{H}$ ) were filled with a mixture of $\mathrm{MHB}$ and mushroom extracts with similar concentrations. Finally, the last three wells were left for positive, quality, and negative controls, respectively.

With the exception, Well \#11 in each row, the contents of Wells \#1 through \#12 were inoculated with $100 \mu \mathrm{L}$ of test organism in triplicate. Chloramphenicol and Clotrimazole drugs $(0.1 \mu \mathrm{g} / \mathrm{mL})$ were served as a positive control against bacterial and yeast species, respectively. The microtiter plate was incubated at $37^{\circ} \mathrm{C}$ and $30^{\circ} \mathrm{C}$ for $24 \mathrm{~h}$ for bacteria and yeast, respectively. After $24 \mathrm{~h}$ of incubation, $50 \mu \mathrm{L}$ of $0.2 \mathrm{mg} / \mathrm{mL}$ TTC was added into the wells of the microtiter plate and then 


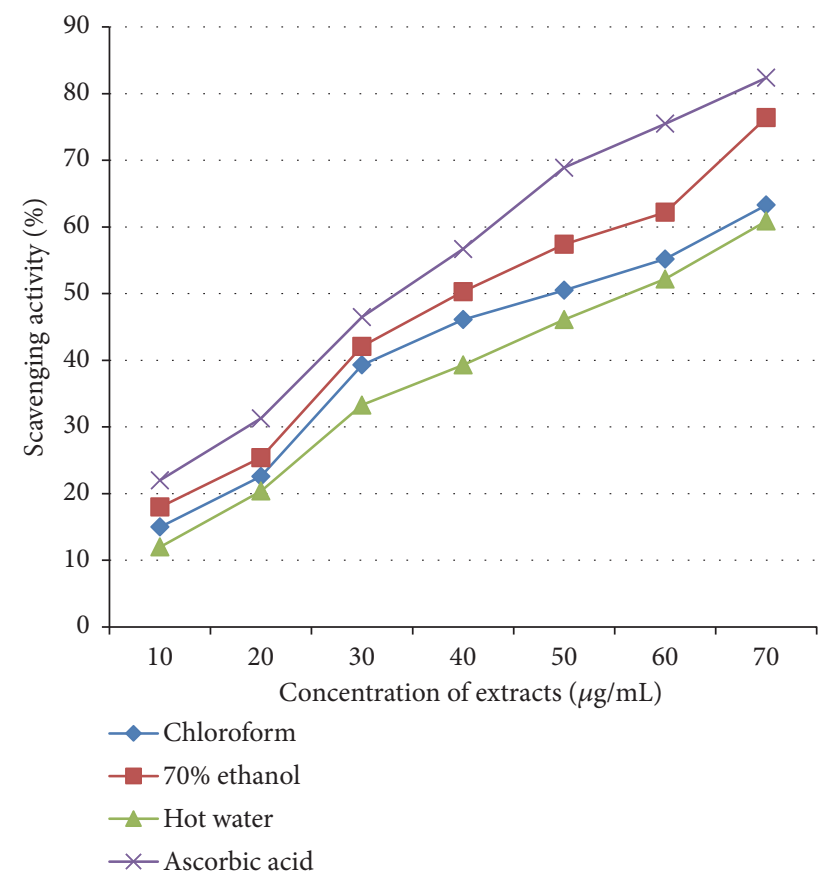

FIgURE 3: Free radical scavenging activities of Auricularia extracts.

incubated for $30 \mathrm{~min}$ to $3 \mathrm{~h}$ at $37^{\circ} \mathrm{C}$ and $30^{\circ} \mathrm{C}$ for bacteria and yeast species, respectively. The MBC and MFC were determined by taking a loopful of inoculum from each well of the microtiter plate and streaking it on Mueller-Hinton and Sabouraud dextrose agar plates for bacteria and yeast species, respectively. The bacteria and yeast-streaked plates were incubated for $24 \mathrm{~h}$ at $37^{\circ} \mathrm{C}$ and $30^{\circ} \mathrm{C}$, respectively.

2.6. Data Collection and Analyses. Data sources are antioxidant activities, MIC, MBC, and MFC. The MIC data were collected by a color change, while MBC and MFC data by growth inhibition of test organisms. Concentrations that result in color change and/or growth inhibition were recorded as data. Then, the data were subjected to ANOVA using the SPSS Version 24.0 statistical software. Inferences were made at $a$ priori significance level of $p \leq 0.05$.

\section{Results}

3.1. Antioxidant Activities of Auricularia Extracts. During the free radical scavenging assay, it was observed that the extracts showed the dose-dependent percentage of scavenging activities. All extracts of Auricularia spp. revealed strong antioxidant activities. The antioxidant activity was expressed by the inhibitory concentration $\left(\mathrm{IC}_{50}\right)$ value, which is the amount of extract needed to decrease $50 \%$ of the initial concentration of the free radical. The extracts were found to be potent antioxidants in the concentration range of $40-60 \mu \mathrm{g} / \mathrm{mL}$ to scavenge and neutralize $50 \%$ of the free radical. The free radical scavenging activity was increased with increased concentrations of the extracts (Figure 3). Even though all extracts of Auricularia spp. revealed promising

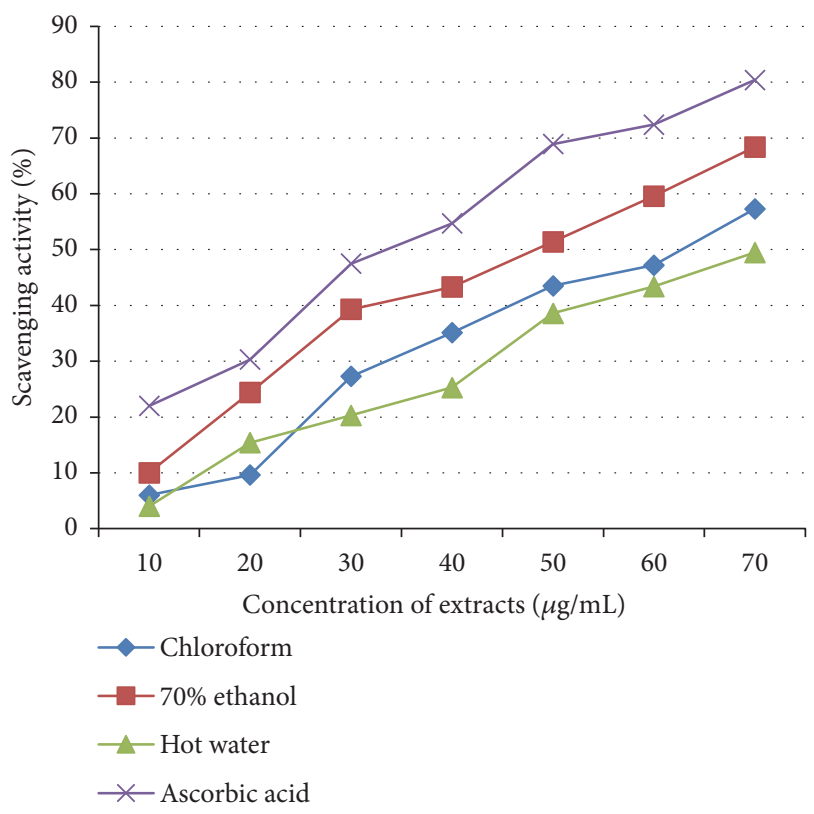

FIGURE 4: Free radical scavenging activity of Termitomyces extracts.

antioxidant activities, they were not as good as the standard antioxidant (ascorbic acid) (Figure 3).

3.2. Antioxidant Activities of Termitomyces Extracts. All extracts of Termitomyces spp. showed considerable free radical scavenging activities at a limited range of concentrations $(10-70 \mu \mathrm{g} / \mathrm{mL})$. The results of the extracts were evaluated and compared with a standard antioxidant (ascorbic acid). But, none of them have revealed better scavenging activity than the standard antioxidant (Figure 4). Of the extracts, $70 \%$ of ethanol extract exhibited the highest scavenging activity (63\%) by demonstrating inhibition concentration $\left(\mathrm{IC}_{50}\right)$ value at $50 \mu \mathrm{g} / \mathrm{mL}$. However, the $\mathrm{IC}_{50}$ values of chloroform and hot water extracts were observed at $65 \mu \mathrm{g} / \mathrm{mL}$ and $70 \mu \mathrm{g} / \mathrm{mL}$, respectively.

3.3. Antimicrobial Activity of Auricularia Extracts. Chloroform, ethanol, and HWE of Auricularia spp. were subjected to antimicrobial screening and the results were promising (Table 1). E. coli, K. pneumoniae (ATCC 13883), C. parapsilosis (ATCC 90018), and S. aureus (ATCC 25923) were observed to be the most resistant organisms to the AMA of the chloroform extract of Auricularia species. Ethanol and HWE have shown the strongest AMA against S. aureus (ATCC 25923). Ethanol extract has resulted in limited AMA against $E$. coli and $P$. aeruginosa (CI). On the other hand, all extracts have resulted in the same AFA against $C$. albicans with chloroform and HWE showing statistically significantly different AMA against $E$. coli $(d f=2, \mathrm{~F}=7, p \leq 0.05)$. All extracts have shown potent AMA against Gram-positive bacteria compared to Gram-negative bacteria and yeast (Table 1).

The MFC of chloroform, ethanol, and hot water extracts of Auricularia spp. were also analyzed and results are presented below (Table 1). HWE has resulted in the strongest 


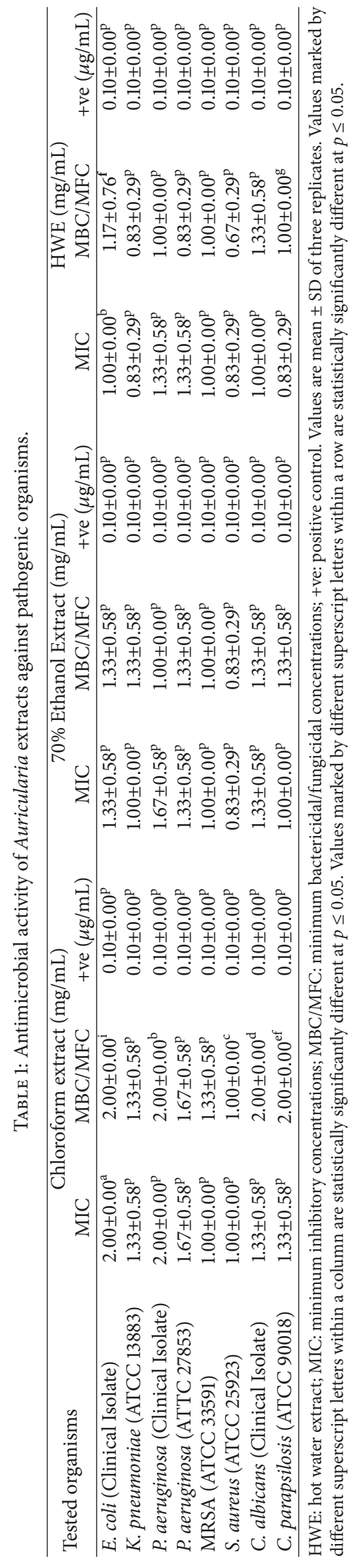


MBC and MFC activities against S. aureus (ATCC 25923) and C. parapsilosis (ATCC 90018), respectively. Chloroform extract has resulted in statistically significantly different AMA against E. coli, P. aeruginosa (CI), S. aureus (ATCC 25923), C. albicans, and C. parapsilosis (ATCC 90018) only $(d f=7, \mathrm{~F}=2.29, p \leq 0.05)$. On the other hand, the chloroform and HWE have shown statistically significantly different AFA against C. parapsilosis (ATCC 90018) $(d f=2, \mathrm{~F}=22.49, p \leq$ 0.05). In conclusion, extracts of Auricularia spp. were generally less effective against E. coli (Gram-negative bacterium) as compared to $S$. aureus (Gram-positive bacterium).

3.4. Antimicrobial Activity of Termitomyces Extracts. Different extracts of Termitomyces spp. were also tested against clinically isolated human pathogens and standard strains. The minimum inhibitory values of hot water extracts against the test organisms ranged from $0.67 \pm 0.29 \mathrm{mg} / \mathrm{mL}$ to $1.00 \mathrm{mg} / \mathrm{mL}$ (Table 2). Of all test organisms, S. aureus (ATCC 25923) was highly susceptible to chloroform, ethanol, and hot water extracts with MIC values of $0.83 \pm 0.29 \mathrm{mg} / \mathrm{mL}, 0.67 \pm$ $0.29 \mathrm{mg} / \mathrm{mL}$, and $0.67 \pm 0.29 \mathrm{mg} / \mathrm{mL}$, respectively. All extracts of Termitomyces spp. were tested for their AMA against E. coli. Chloroform and HWE have shown statistically significantly different growth inhibitory activities against $E$. coli $(d f=2, \mathrm{~F}$ $=5.6, p \leq 0.05$ ).

HWE was active against S. aureus (ATCC 25923), K. pneumoniae (ATCC 13883), P. aeruginosa (CI), P. aeruginosa (ATTC 27853), MRSA (ATCC 33591), and C. albicans. S. aureus (ATCC 25923) was found to be the most susceptible bacterium to HWE followed by $K$. pneumoniae (ATCC 13883), MRSA (ATCC 33591), P. aeruginosa (CI), P. aeruginosa (ATTC 27853), and C. albicans. HWE was found to be more potent against $C$. albicans (CI) than C. parapsilosis (ATCC 90018). On the other hand, E. coli (CI) was found to be the most resistant organism to HWE. These results showed that the HWE of Termitomyces spp. possesses AFA and ABA.

\section{Discussion}

In the current study, all extracts of Auricularia and Termitomyces spp. were found to be potent antioxidants in the concentration range of $40-60 \mu \mathrm{g} / \mathrm{mL}$ and $10-70 \mu \mathrm{g} / \mathrm{mL}$, respectively. However, a previous study reported that the radical scavenging activity of mushroom extracts was shown at $2.11 \mathrm{mg} / \mathrm{mL}$ [26]. The possible reasons for the varied results of antioxidant activities between the present and previous study might be due to the different extraction conditions, and the difference in the presence of phenolic compounds and other secondary metabolites [27-29]. Many other studies also reported that phenolic compounds obtained from mushroom extracts have shown excellent antioxidant activities by scavenging free radicals [30-33].

Auricularia and Termitomyces spp. extracts have shown remarkable AMA against the test organisms. However, the chloroform, 70\% ethanol, and HWE of Auricularia and Termitomyces extracts have exhibited varying degrees of AMA. The observed variations may be due to the presence of different bioactive substances and their mechanism of action against test pathogenic organisms. Moreover, the AMA difference among the extracts of the two mushrooms could be attributed to their difference in species and variations in the composition and concentrations of secondary metabolites within the extracts [34]. Another result obtained from the research done on the AMA of some local mushrooms against pathogenic isolates also suggested that the AMA of the extracts might have various potent bioactive compounds [12]. A study conducted on the AMA of extracts of Trametes elegans also reported that the differences in the AMA of the extracts have been mainly attributed to the ability of solvents to extract different bioactive components from the mushrooms [35, 36]. Similarly, Barros et al. [37] findings also verified that the AMA of the mushroom extracts were a result of the presence of various arrays of secondary metabolites.

The findings of the current study indicated that HWE of Auricularia and Termitomyces mushrooms have shown strong ABA against $S$. aureus compared to other test organisms. This might be associated with the synergistic effect and the broad-spectrum ABA of HWE. A study done by Cai et al. [38] also established that the HWE of Auricularia auricula-judae exhibited the greatest $\mathrm{ABA}$ against $S$. aureus. The observed disparity in the AMA of HWE against the test organisms may be correlated with its higher polarity and ability to extract powerful bioactive compounds. In corroborative to the present findings, previous studies also reported that polar solvents were found to be the most effective in extracting potent organic and inorganic mycochemicals [39]. The chemical nature of the bioactive compounds and the type and $\mathrm{pH}$ of the solvents can also have an influence on the AMA of the extracts [22]. Furthermore, the strong AMA of HWE against the microbes could be attributed to its ability to dissolve endogenous compounds [40].

On the other hand, the Auricularia and Termitomyces species chloroform and ethanol extracts revealed weaker AMA against test organisms. A previous study also reported that $70 \%$ of alcohol was not effective in extracting antimicrobial compounds from the fruiting bodies of $P$. ostreatus, which is related to the present findings [41]. The weak AMA of the chloroform and ethanol extracts might be the absence of bioactive compounds in the extracts or lost activities due to heat or chemical transformation into inactive products during extraction [12]. These deviations might also be associated with the difference in the contents and concentrations of the antimicrobial compounds present in the aqueous and organic solvent extracts $[42,43]$.

All extracts of Auricularia and Termitomyces species exhibited high AMA against Gram-positive bacteria compared to Gram-negative bacteria and yeast, which approves the previous results on the $\mathrm{ABA}$ of aqueous extracts of eight edible mushrooms [44]. It was proven that bioactive compounds obtained from the extracts of many mushroom spp. demonstrated higher antimicrobial activities against Gram-positive compared to Gram-negative bacteria [45]. The variation of AMA observed between the Gram-negative and Gram-positive bacteria might be attributed to the nature of genetic makeup of the tested organisms, structure, 


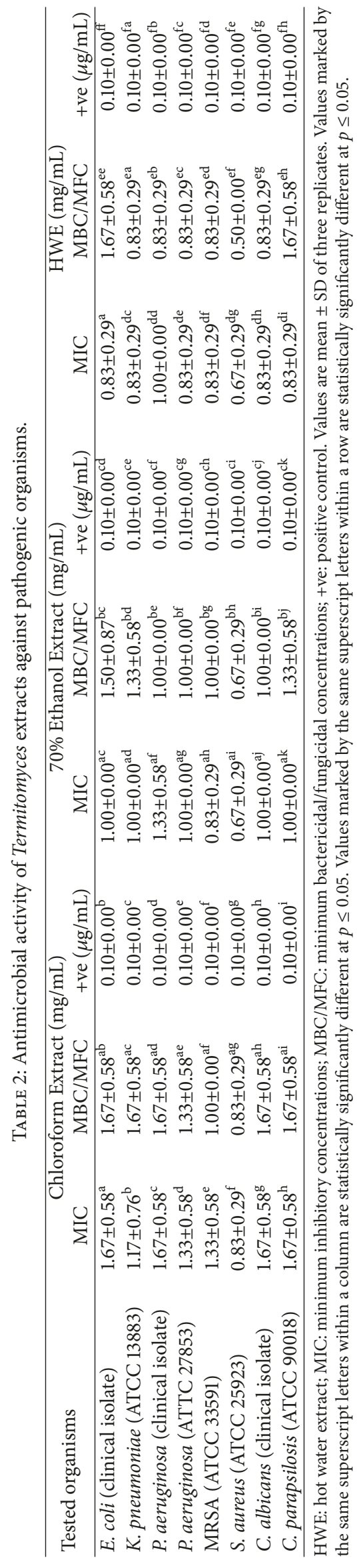


composition differences of the cell wall of the bacteria, mycochemical composition, and concentrations of the extracts, type, and nature of solvents used for extraction, and mechanisms of actions of bioactive compounds [22, 46-48].

All tested extracts have shown a marked difference in their AMA towards the clinical isolates and standard strains. The clinical bacteria and yeast isolates were found to be more resistant to the extracts than the standard strains. The main reason for the resistance of the clinical isolates might be directly linked to the indiscriminate exposure of the clinical isolates to various antimicrobial agents [48, 49]. According to Taiwo [50], several clinical isolates have effective antibiotic resistance mechanisms through the acquisition of resistant genes, production of enzymes (e.g., B-lactamases), and efflux pumping of the drug out of the cell.

\section{Conclusion}

All extracts of Auricularia and Termitomyces mushrooms have revealed potent antioxidant activities. They have also shown promising antimicrobial activities against the tested organisms. Of all extracts, hot water extract of both mushroom species has shown strong antibacterial activity against $S$. aureus. However, further studies into isolation, structural elucidation, identification, and determination of the mechanisms of action of the bioactive compounds of the mushroom extracts responsible for the antioxidant and antimicrobial activities are compulsory.

\section{Abbreviations}

AMA: Antimicrobial activity

ABA: Antibacterial activity

AFA: Antifungal activity

MRSA: Meticillin resistant Staphylococcus aureus

CFU: Colony forming unit

CI: $\quad$ Clinical isolates

HWE: Hot water extract

MIC: Minimum inhibitory concentration

MFC: Minimum fungicidal concentration

MBC: Minimum bactericidal concentration

MHB: Mueller-Hinton broth

ANOVA: One-Way Analysis of Variance

DMSO: Dimethyl sulfoxide.

\section{Data Availability}

The data used to support the findings of this study are included within the article. In any case, if the data used to support the findings of this study are required by anybody, they are available from the corresponding author upon request.

\section{Conflicts of Interest}

The authors declare that there are no conflicts of interest.

\section{Acknowledgments}

The authors acknowledge Pan African University, Institute for Basic Sciences, Technology and Innovation, Africa-ai-Japan Project, and Mekelle University for financial support. The authors would also like to thank the Kenya Medical Research Institute for giving us a laboratory facility for the research.

\section{References}

[1] L. Xu, W. Meng, C. Cao, J. Wang, W. Shan, and Q. Wang, "Antibacterial and antifungal compounds from marine fungi," Marine Drugs, vol. 13, no. 6, pp. 3479-3513, 2015.

[2] Y. Gao, W. Tang, H. Gao et al., "Antimicrobial activity of the medicinal mushroom Ganoderma," Food Reviews International, vol. 21, no. 2, pp. 211-229, 2005.

[3] M. Sevindik, "Investigation of antioxidant/oxidant status and antimicrobial activities of lentinus tigrinus," Advances in Pharmacological Sciences, vol. 2018, Article ID 1718025, 4 pages, 2018.

[4] G. Gebreyohannes, A. Nyerere, C. Bii, and D. B. Sbhatu, "Determination of antimicrobial activity of extracts of indigenous wild mushrooms against pathogenic organisms," EvidenceBased Complementary and Alternative Medicine, vol. 2019, pp. $1-7,2019$.

[5] I. González-Palma, H. B. Escalona-Buendía, E. Ponce-Alquicira et al., "Evaluation of the antioxidant activity of aqueous and methanol extracts of Pleurotus ostreatus in different growth stages," Frontiers in Microbiology, vol. 7, pp. 1-32, 2016.

[6] H. Badshah, F. Ullah, M. U. Khan, A. S. Mumtaz, and R. N. Malik, "Pharmacological activities of selected wild mushrooms in South Waziristan (FATA), Pakistan," South African Journal of Botany, vol. 97, pp. 107-110, 2015.

[7] M. L. Gargano, U. Lindequist, G. Venturella, SP. Wasser, and G. I. Zervakis, "Medicinal mushrooms: Valuable biological resources of high exploitation potential," Plant Biosystems - An International Journal Dealing with all Aspects of Plant Biology, vol. 151, no. 3, pp. 530-547, 2017.

[8] A. F. M. H. Iftekhar, Z. K. Choudhry, M. I. Khan, and A. A. Saleh, "Comparative study of antibacterial activity of wood-decay fungi and antibiotics," Bangladesh Journal of Pharmacology, vol. 6, no. 1, pp. 14-17, 2011.

[9] M. J. Alves, I. F. R. Ferreira, J. Dias, V. Teixeira, and A. Martins, "A review on antimicrobial activity of mushroom (Basidiomycetes) extracts and isolated compounds," Planta Medica, vol. 78, no. 16, pp. 1707-1718, 2012.

[10] G. Waktola and T. Temesgen, "Application of mushroom as food and medicine," Advances in Biotechnology and Microbiology, vol. 113, pp. 1-4, 2018.

[11] K. R. Ranadive, M. H. Belsare, S. S. Deokule, N. V. Jagtap, H. K. Jadhav, and J. G. Vaidya, "Glimpses of antimicrobial activity of fungi from world," Journal on New Biological Reports, vol. 2, no. 2, pp. 142-162, 2013.

[12] O. E. Udu-Ibiam, O. Ogbu, O. Nworie, U. A. Ibiam, M. V. Agah, A. U. Nnachi et al., "Antimicrobial activities of some selected edible mushrooms and spices against clinical isolates from federal university teaching hospital," International Journal of Scientific \& Technology Research, vol. 3, no. 5, pp. 251-255, 2014.

[13] C. S. G. Kitzberger, A. Smânia, R. C. Pedrosa et al., "An examination of antibacterial and antifungal properties of constituents of Shiitake (Lentinula edodes) and Oyster (Pleurotus ostreatus) 
mushrooms," Journal of Food Engineering, vol. 15, no. 1, pp. 5-7, 2009.

[14] G. F. Bills and J. B. Gloer, "Biologically active secondary metabolites from the fungi," Microbiology Spectrum, vol. 4, no. 6, pp. 1-32, 2016.

[15] J. M. Hussein, D. D. Tibuhwa, A. M. Mshandete, and A. K. Kivaisi, "Antioxidant properties of seven wild edible mushrooms from Tanzania," African Journal of Food Science, vol. 9, no. 9, pp. 471-479, 2015.

[16] A. Alispahic and M. Salihovic, "Phenolic content and antioxidant activity of mushroom extracts from Bosnian market Phenolic content and antioxidant activity of mushroom extracts from Bosnian market," Bulletin of the Chemists and Technologistsof Bosnia and Herzegovina, vol. 44, pp. 5-8, 2015.

[17] S. Rediet, M. Anteneh, and A. Dawit, "Morphological and molecular studies on Termitomyces species species of menge district, asossa zone, northwest ethiopia," Science, Technology and Arts Research Journal, vol. 4, no. 4, pp. 49-57, 2015.

[18] B. O. Onyango, C. M. Mbaluto, C. S. Mutuku, and D. O. Otieno, "Molecular characterization of wood ear mushrooms [Auriculariasp.] from Kakamega Forest in Western Kenya," Current Research in Environmental \& Applied Mycology, vol. 6, no. 1, pp. 51-60, 2016.

[19] A. R. Bandara, J. Chen, S. Karunarathna, K. D. Hyde, and P. Kakumyan, "Auricularia thailandica sp. nov. (Auriculariaceae, Auriculariales) a widely distributed species from Southeastern Asia," Phytotaxa, vol. 208, no. 2, pp. 147-156, 2015.

[20] B. O. Onyango, V. A. Palapala, P. F. Arama, S. O. Wagai, and B. M. Gichimu, "Morphological characterization of Kenyan native wood ear mushroom [Auricularia auricula (L. ex Hook.) Underw.] and the effect of supplemented millet and sorghum grains in spawn production," Agriculture and Biology Journal of North America (ABJNA), vol. 2, no. 3, pp. 407-414, 2011.

[21] A. R. Bandara, S. C. Karunarathna, A. J. Phillips et al., "Diversity of auricularia (Auriculariaceae, Auriculariales) in thailand," Phytotaxa, vol. 291, no. 1, pp. 19-34, 2017.

[22] S. Kalaw and R. Albinto, "Functional activities of Philippine wild strain of Coprinus comatus (O.F.Müll.: Fr.) Pers and Pleurotus cystidiosus O. K. Miller grown on rice straw based substrate formulation," Mycosphere, vol. 5, no. 5, pp. 646-655, 2014.

[23] D. Menaga, S. Rajakumar, and P. M. Ayyasamy, "Free radical scavenging activity of methanolic extract of pleurotus florida mushroom," International Journal of Pharmacy and Pharmaceutical Sciences, vol. 5, no. 4, pp. 601-606, 2013.

[24] P. Molyneux, "The use of the stable radical Diphenylpicrylhydrazyl (DPPH) for estimating antioxidant activity," Songklanakarin Journal of Science and Technology, vol. 26, no. 2, pp. 211-219, 2004.

[25] M. Pandithurai and S. Murugesan, "Free radical scavenging activity of methanolic extract of brown alga Spatoglossum asperum," Journal of Chemical and Pharmaceutical Research, vol. 6, no. 7, pp. 128-132, 2014.

[26] M. Joshi and A. Sagar, "In vitro free radical scavenging activity of a wild edible mushroom, Sparassis crispa (Wulf.) Fr., from north western himalayas, india," Journal of Mycology, vol. 2014, pp. 1-4, 2014.

[27] M. Elmastas, O. Isildak, I. Turkekul, and N. Temur, "Determination of antioxidant activity and antioxidant compounds in wild edible mushrooms," Journal of Food Composition and Analysis, vol. 20, no. 3-4, pp. 337-345, 2007.
[28] T. Ozen, C. Darcan, O. Aktop, and I. Turkekul, "Screening of antioxidant, antimicrobial activities and chemical contents of edible mushrooms wildly grown in the Black Sea region of Turkey," Combinatorial Chemistry \& High Throughput Screening, vol. 14, no. 2, pp. 72-84, 2011.

[29] G. Solmaz, F. Ozen, Y. Ekinci, P. S. Bird, and M. Korachi, "Inhibitory and disruptive effects of Shiitake mushroom (Lentinula edodes) essential oil extract on oral biofilms," Jundishapur Journal of Microbiology, vol. 6, no. 9, pp. 1-6, 2013.

[30] N. P. Das and A. Ratty, "Effects of flavonoids on nonenzymatic lipid peroxidation: Structure-activity relationship," Biochemical Medicine and Metabolic Biology, vol. 39, no. 1, pp. 69-79, 1988.

[31] T. C. Finimundy, G. Gambato, R. Fontana et al., "Aqueous extracts of Lentinula edodes and Pleurotus sajor-caju exhibit high antioxidant capability and promising in vitro antitumor activity," Nutrition Research, vol. 33, no. 1, pp. 76-84, 2013.

[32] Y. Ishikawa, K. Morimoto, and T. Hamasaki, "Flavoglaucin, a metabolite of Eurotium chevalieri, its antioxidation and synergism with tocopherol," Journal of the American Oil Chemists' Society, vol. 61, no. 12, pp. 1864-1868, 1984.

[33] C. A. Rice-Evans, N. J. Miller, and G. Paganga, "Structureantioxidant activity relationships of flavonoids and phenolic acids," Free Radical Biology \& Medicine, vol. 20, no. 7, pp. 933956, 1996.

[34] F. Kalyoncu, M. Oskay, H. Sağlam, T. F. Erdoğan, and A. U. Tamer, "Antimicrobial and antioxidant activities of mycelia of 10 wild mushroom species," Journal of Medicinal Food, vol. 13, no. 2, pp. 415-419, 2010.

[35] A. Hartmann, A. Schikora, K. P. Rumbaugh et al., "Antimicrobial properties of the mushroom Agaricus blazei - integrative review," Revista Brasileira de Farmacognosia, vol. 48, no. 9, pp. 186-211, 2017.

[36] S. Rathee, D. Rathee, D. Rathee, V. Kumar, and P. Rathee, "Mushrooms as therapeutic agents," Revista Brasileira de Farmacognosia, vol. 22, no. 2, pp. 459-474, 2012.

[37] S. P. Wasser, "Medicinal mushroom science: current perspectives, advances, evidences, and challenges," Biomedical Journal, vol. 37, no. 6, pp. 345-356, 2014.

[38] M. Cai, Y. Lin, Y.-L. Luo, H.-H. Liang, and P.-L. Sun, "Extraction, antimicrobial, and antioxidant activities of crude polysaccharides from the wood ear medicinal mushroom Auricularia auricula-judae (higher basidiomycetes)," International Journal of Medicinal Mushrooms, vol. 17, no. 6, pp. 591-600, 2015.

[39] D. Ojwang, J. M. Onguso, and J. Harvey, "Genetic diversity of Kenyan native oyster mushroom (Pleurotus)," Mycologia, vol. 107, no. 1, pp. 32-38, 2014.

[40] J. Panda, P. Dash, T. P. Nayak, and N. Gupta, "Antimicrobial properties of native mushrooms of urban environment of Bhubaneswar, Odisha," Mushroom Research, vol. 26, no. 1, pp. 69-75, 2017.

[41] A. M. Younis, F.-S. Wu, and H. H. El Shikh, "Antimicrobial activity of extracts of the oyster culinary medicinal mushroom Pleurotus ostreatus(Higher Basidiomycetes) and identification of a new antimicrobial compound," International Journal of Medicinal Mushrooms, vol. 17, no. 6, pp. 579-590, 2015.

[42] J. Glamoclija and M. Sokovic, "Fungi a source with huge potential for 'mushroom pharmaceuticals"' Lekovite Sirovine, no. 37, pp. 52-57, 2017.

[43] A. R. Das, A. K. Saha, S. R. Joshi, and P. Das, "Wild edible macrofungi consumed by ethnic tribes of Tripura in Northeast India with special reference to antibacterial activity of Pleurotus 
djamor (Rumph. ex Fr.) Boedijn," International Food Research Journal, vol. 24, no. 2, pp. 834-838, 2017.

[44] L. Ren, Y. Hemar, C. O. Perera, G. Lewis, G. W. Krissansen, and P. K. Buchanan, "Antibacterial and antioxidant activities of aqueous extracts of eight edible mushrooms," Bioactive Carbohydrates and Dietary Fibre, vol. 3, no. 2, pp. 41-51, 2014.

[45] S. I. Awala and V. O. Oyetayo, "The phytochemical and antimicrobial properties of the extracts obtained from Trametes elegans collected from Osengere in Ibadan, Nigeria," Jordan Journal of Biological Sciences, vol. 8, no. 4, pp. 289-299, 2015.

[46] V. O. Oyetayo, C. H. Dong, and Y. J. Yao, "Antioxidant and antimicrobial properties of aqueous extract from Dictyophora indusiata," The Open Mycology Journal, vol. 3, pp. 20-26, 2009.

[47] K. B. P. B. Casaril, M. C. M. Kasuya, and M. C. D. Vanetti, "Antimicrobial activity and mineral composition of shiitake mushrooms cultivated on agricultural waste," Brazilian Archives of Biology and Technology, vol. 54, no. 5, pp. 991-1002, 2011.

[48] T. Appiah, Y. D. Boakye, and C. Agyare, "Antimicrobial activities and time-kill kinetics of extracts of selected ghanaian mushrooms," Evidence-Based Complementary and Alternative Medicine, vol. 2017, Article ID 4534350, 15 pages, 2017.

[49] E. Liktor-Busa, B. Kovács, E. Urbán, J. Hohmann, and A. Ványolós, "Investigation of Hungarian mushrooms for antibacterial activity and synergistic effects with standard antibiotics against resistant bacterial strains," Letters in Applied Microbiology, vol. 62, no. 6, pp. 437-443, 2016.

[50] S. S. Taiwo, "Antibiotic-resistant bugs in the 21st century: a public health challenge," World Journal of Clinical Infectious Diseases, vol. 1, no. 1, p. 11, 2011. 


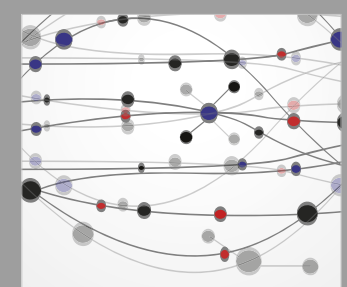

The Scientific World Journal
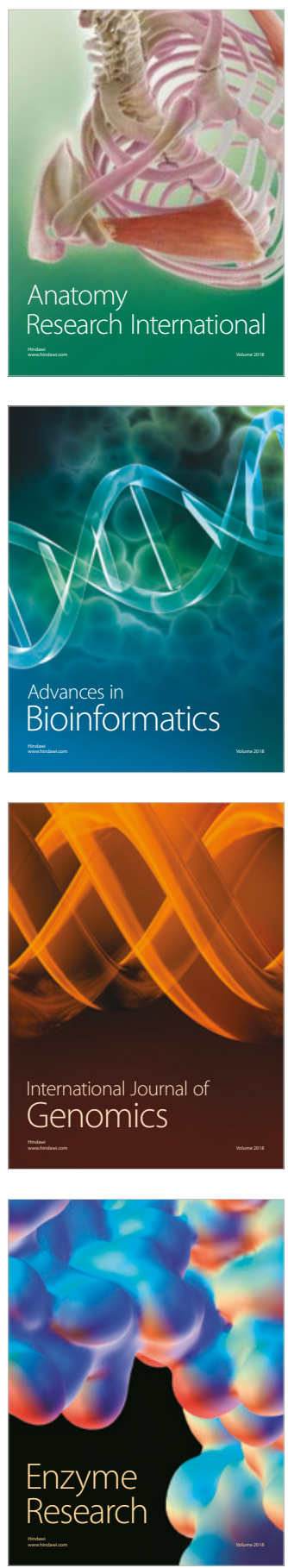
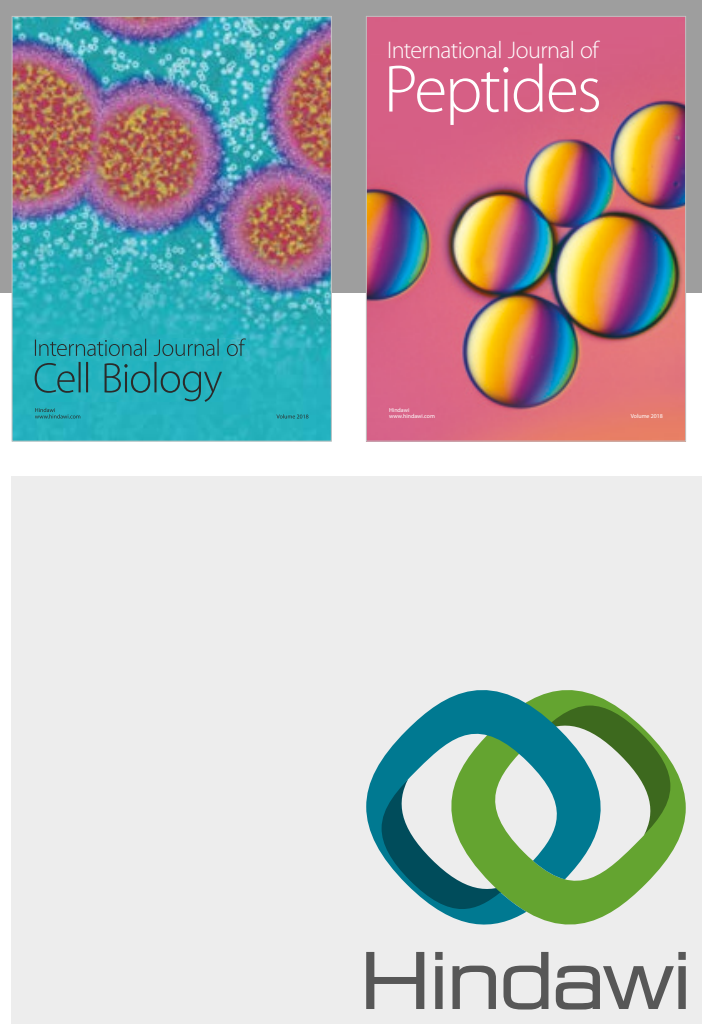

Submit your manuscripts at

www.hindawi.com
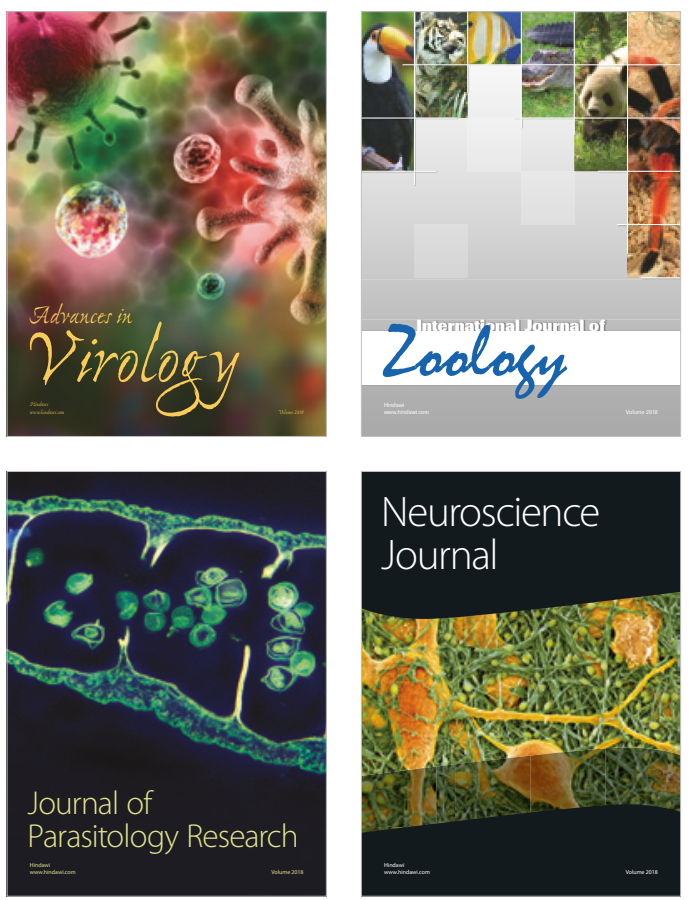
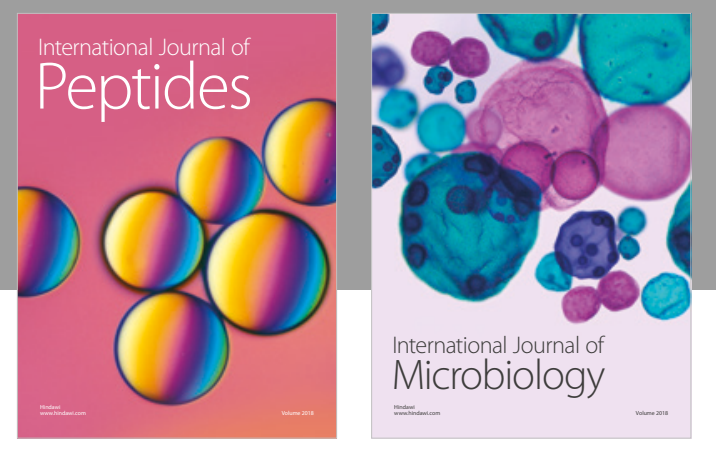

nternational Journal of Microbiology
Journal of
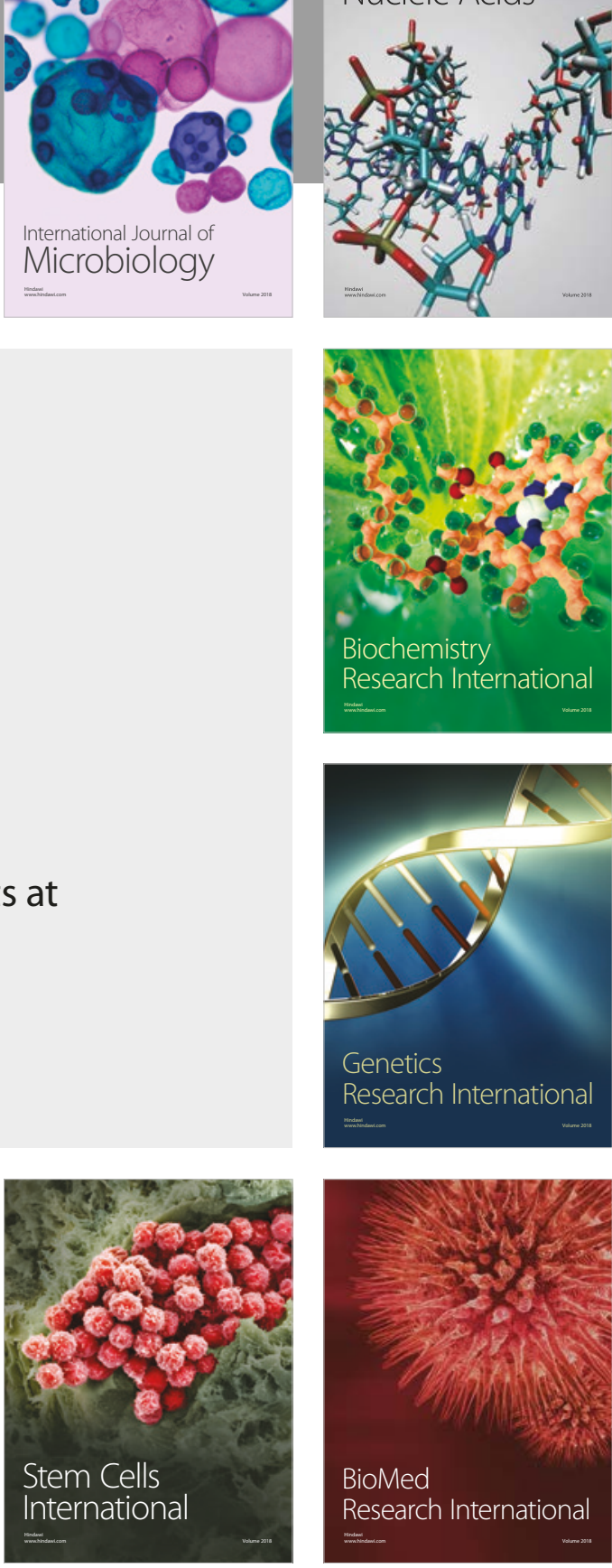
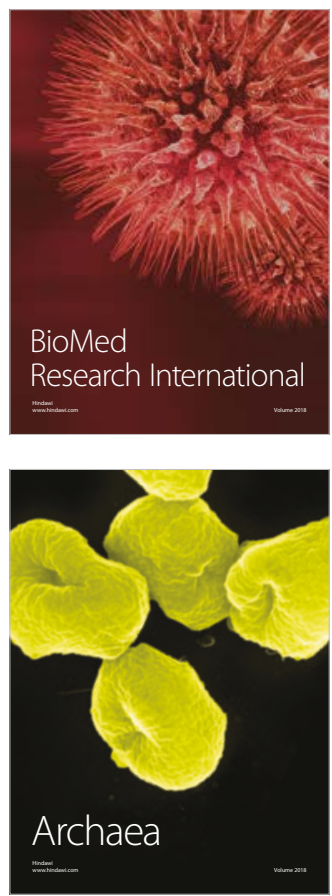